\title{
Эффективность и безопасность послеоперационной аналгезии кеторолаком и трамадолом в зависимости от наличия полиморфизмов CYP2D6 и CYP2C9
}

\author{
Мурадян А. А., Сычёв Д. А., Благовестнов Д. А. \\ ФГБОУ ДПО «Российская медицинская академия непрерывного профессионального образования» \\ МЗ РФ, Россия, Москва
}

Ключевые слова: послеоперационная аналгезия; трамадол; кеторолак; полиморфизмов генов; полиморфизм CYP2D6; полиморфизм CYP2C9

\section{Для цитирования:}

Мурадян А.А., Сычёв Д.А., Благовестнов Д.А. Эффективность и безопасность послеоперационной аналгезии кеторолаком и трамадолом в зависимости от наличия полиморфизмов CYP2D6 и CYP2C9 // Фармакогенетика и фармакогеномика. 2020;(2):14-15. (In Russ). DOI: 10.37489/2588-0527-2020-2-14-15

Введение. Эффективность обезболиваюшей терапии и профиль нежелательных лекарственных реакций в значительной степени зависят от генетических особенностей [1]. Аллельные варианты генов, представляющие собой полиморфные участки генов, влияют как на фармакокинетику, так и на фармакодинамику лекарственных средств [2]. Гены, включая семейство СYР или СОМТ / АВCB1 / OPRM1, могут влиять на метаболизм наркотических анальгетиков и нестероидных противовоспалительных средств. Генетические варианты зародышевой линии кодируют ферменты, метаболизирующие лекарственные средства, переносчики лекарств, мишени для лекарств и главный комплекс гистосовместимости (HLA), которые влияют на индивидуальный ответ на лекарственный препарат [3]. Из-за трудоёмкости и ресурсоёмкости секвенирования всего генома в современном фармакогенетическом тестировании часто используется подход «гена-кандидата», который определяет влияние генотипа на биотрансформацию конкретного лекарственного средства у пациента [4]. Для НПВП геном-кандидат, который может влиять на их биотрансформацию, в частности на фармакокинетику, является CYP2C9 [5]. Для трамадола таким геном-кандидатом является CYP2D6 [5].

Цель. Оценить возможную связь полиморфизмов CYP2D6 и CYP2C9 с эффективностью и безопасностью применения комбинации трамадола и кеторолака при послеоперационном обезболивании.

Материалы и методы. В исследование были включены 107 пациентов с неосложнённым острым калькулёзным холециститом, которые лечились в соответствии с оптимизированным протоколом ускоренного выздоровления. Пациенты были генотипированы по полиморфным маркерам CYP2D6 и СУР2С9. Объём операции для каждого пациента - видеолапароскопическая холецистэктомия. Послеоперационная анестезия была строго регламентированной, мультимодальной, с использованием препаратов 2 групп и проводилась по схеме: с применением трамадола $5 \%$ 2,0 в/м через 6 ч после операции (однократно) и кеторолака 2, 0 в/м 4 раза в сутки в первые 2-3 дня после операции, затем при необходимости продолжался пероральный приём. Для оценки послеоперационного болевого синдрома использовали визуальную аналоговую шкалу и болевой опросник МакГилла. Профиль побочных эффектов оценивался по динамике показателей красной крови, как возможного триггера развития побочных реакций, в частности желудочно-кишечного кровотечения, с использованием метода глобальной оценки триггеров.

Результаты. У носителей полиморфного маркера $C Y P 2 D 6^{*} 4$ болевой синдром был выше по сравнению с диким типом, во все временные интервалы, но статистически значимые результаты были получены только через 2 часа - на $1,01(p=0,054)$ и через 24 часа - на $0,8(p=0,035)$. У носителей $C Y P 2 C 9^{*} 2$ интенсивность болевого синдрома была статистически значимо ниже по данным ВАШ: через 12 часов на $1,5(p=0,002)$; через 24 часа - на $1,1(p=0,012)$; через 36 часов - на $1,05(p=0,004)$; через 48 часов на $0,7(p=0,026)$.

Носители полиморфного маркера СYP2C9*2 показали более выраженное снижение абсолютной и относительной разницы гемоглобина до и после применения кеторолака на $2,5 \%(p=0,002)$ и $1,7 \%$ $(p=0,003)$, соответственно, по сравнению с диким типом. Абсолютная и относительная разница эритроцитов также была более выражена у носителей 
мутантного аллеля $C Y P 2 C 9 * 2$ по сравнению с диким типом - на $0,043 \%(p=0,014)$ и $0,825 \%(p=0,019)$, соответственно.

Носители полиморфного маркера $C Y P 2 C 9 * 3$ также показали более выраженное уменьшение абсолютной и относительной разницы гемоглобина до и после применения кеторолака на $3,2 \%(p=0,000087)$ и $2,2 \%(p=0,000143)$, соответственно, по сравнению с носители дикого типа. Абсолютная и относительная разница эритроцитов также была более выражена у носителей мутантного аллеля $C Y P 2 C 9 * 3$ по сравнению с диким типом - на $0,031 \%$ ( $p=$
$0,105714)$ и $0,64 \%(p=0,103879)$, соответственно.

Заключение. Полиморфные маркеры CYP2D6 и CYP2C9 могут прогнозировать анальгетическую эффективность трамадола и кеторолака. Полиморфный маркер CYP2C9 может прогнозировать риск развития побочных реакций, в частности желудочно-кишечных кровотечений, в том числе скрытых при применении кеторолака.

Исследование поддержано государственным грантом Президента Российской Федерации: НШ-2698.2020.7 om 2019 г.

\section{Литература / References}

1. Ladak SSJ, Chan VWS, Easty T, Chagpar A. Right medication, right dose, right patient, right time, and right route: how do we select the right patient-controlled analgesia (PCA) device? Pain Manag Nurs. 2007;8(4):140-5. DOI: 10.1016/j.pmn.2007.08.001.

2. Кукес В.Г., Сычев Д.А., Раменская Г.В., Игнатьев И.В. Фармакогенетика системы биотрансформации и транспортеров лекарственных средств: от теории к практике // Биомедицина. 2007;6:29-47. [Kukes VG, Sychev DA, Ramenskaya GV, Ignat'ev IV. Pharmacogenetics of system of biotransformation and drugs transporters: from the theory to practice. Biomeditsina. 2007;6:29-47. (In Russ).].
3. Ko TM, Wong CS, Wu JY, Chen YT. Pharmacogenomics for personalized pain medicine. Acta Anaesthesiol. Taiwan. 2016;54(1):24-30. DOI: 10.1016/j.aat.2016.02.001.

4. Crews KR, Hicks JK, Pui $\mathrm{CH}$ et al. Pharmacogenomics and individualized medicine: translating science into practice. Clin Pharmacol Ther. 2012;92(4):467-75. DOI: 10.1038/clpt.2012.120.

5. Tomalik-Scharte D, Lazar A, Fuhr U, Kirchheiner J. The clinical role of genetic polymorphisms in drug-metabolizing enzymes. Pharmacogenomics J. 2008;8(1):4-15. DOI: 10.1038/sj.tpj.6500462. 